\title{
Barriers to climate adaptation in urban areas: The case of water crisis in the Metropolitan Region of São Paulo ${ }^{1}$
}

Ana Helena Palermo Kuss

DOI - 10.25160/v5i2.d4

\section{Introduction}

The goal of a growing economy poses different kinds of challenges to those who are a part of it. One of them is how to provide the material resources needed to keep on a certain growth and social development path. When it comes to natural resources, one of the most mentioned is oil, but water is also an essential input of productive activities. Growth in population and in consumption also generates a greater demand for water. As the amount and mobility of water has its specific restrictions, it is essential to understand its particularities and interplay with political decisions to guarantee a safe provision of this resource, not just for economic growth, but above all for human security.

The targeted region of this paper is the Metropolitan Region of São Paulo (MRSP). This region was chosen, firstly, because it has been facing a water crisis since at least the summer 2013/2014 when it was hit by a prolonged period of drought in the southeastern region of Brazil. The main water supplier of this region, the Cantareira system, reached $-23 \%$ of its usable capacity in February, 2015 (Sabesp). The negative sign means that the water level was below the level of withdrawal per gravity and that the water withdrawn in this situation belongs to a "dead volume", whose function is to guarantee the sustainability of the reservoir and, therefore, should remain untouched. In October 2014 water shortage affected about $60 \%$ of the population (Folha de São Paulo, October 20, 2014). This was not the only region in Brazil affected by the drought; other Brazilian states like Minas Gerais and Rio de Janeiro were also affected. Thinking about water crisis in a water rich country such as Brazil may seem controversial, but about $80 \%$ of Brazil's water availability is concentrated in the Amazon region (ANA 2013), some hundreds of kilometers away from MRSP. Secondly, MRSP is responsible for $17.89 \%$ of the Brazilian GDP (IBGE and SEADE 2012), concentrates about 10\% of its

${ }^{1}$ A previous version of this paper was published as a working paper in the Constitutional Economics Network (CEN) Working Papers No. 04-2015 (ISSN 2193-7214).

RRASILIANA- Journal for Brazilian Studies. Vol. 5, n.2 (July, 2017). ISSN 2245-4373.. 
population (IBGE and SEADE 2014) and corresponds just to $0.09 \%$ of the Brazilian territory, i.e. it has a high weight on the Brazilian economy.

The key reference of this paper is the literature on barriers to adaptation to climate change. The issue of climate variability is here one of the important backgrounds, as the water provision in the region collapsed in a moment that followed a prolonged period of drought. This paper aims at identifying and explaining which barriers contributed to the low resilience of the region concerning the variabilities in rain fall. The central question is: why was there not better preparation for a possible drought period in the MRSP? This question is disentangled into two sub-questions: (1) Which barriers to adaptation (water security) were encountered and (2) how did they emerge?

The paper utilizes the definition of barriers as "an impediment to specified adaptations for specified actors in their given context that arise from a condition or set of conditions" (Eisenack et al. 2014, p. 868). In line with this concept, climate adaptation is defined as actions by individual or collective actors in response to anticipated or experienced impacts of climate variability, change, and extreme events. (Eisenack and Stecker 2012; Klein and Johula 2014; Oberlack 2014). Institutions are the formal and informal rules and procedures that structure action situations within which individual and collective decision-making takes place (Ostrom 2005). To classify barriers, the typology designed by Ekstrom and Moser (2012) is used. Furthermore, the research problem is framed based on the concept of water security, i.e. "the availability of an acceptable quantity and quality of water for health, livelihoods, ecosystems and production, coupled with an acceptable level of water related risks to people, environments and economies" (Grey and Sadoff 2007; Wang et al. 2012; Grey et al. 2013; Garrick et al. 2013). This paper focuses on risks related to scarcity, those related to water excess, such as floods do not belong to its scope.

In the literature on barriers, institutional factors, among others, are frequently identified as important to understand how societies develop their adaptation strategies. There is a broad consensus in this literature that institutions matter for climate adaptation (Klein et al. 2014, Oberlack 2016). It does not mean, nevertheless, that there are panaceas to be followed. Researchers should be aware of and explain context and actor specific barriers, which concern particular cases. In this line, the ability of general institutional design principles to successfully foster adaptation is questioned (Oberlack 2016). Therefore, one central milestone here is to go beyond panaceas for water institutions. This study does not depart from the assumption that decentralization and integrated management are necessarily an ideal path for successful water governance in the MRSP, like, for example, in Johnsson and Kemper (2005). Among the 
identified barriers is the problem of an exclusive political system, which is not necessarily a consequence of a centralized governance structure, but more a problem of lack of representativeness in different levels of this structure.

Few studies in the literature on barriers address the level of local decision-makers and most of them are focused on industrialized countries (Biesbroek et al. 2013). Focusing on a local governance level in an emerging country and having in mind the influence of multiple governance levels, this study contributes to this literature.

The paper is organized in five further sections. In the next one the political and historical context of the current water crisis is briefly presented. Section three describes the conceptual framework, theory and methods used in the study design. In section four the framework is applied to describe the focal social-ecological system. Section five presents the results of the field research, and section six discusses how these findings contribute to answering the research questions and how they are related to the presented theory. Finally, section seven draws some conclusions.

\section{Political and historical context}

From April 2013 to February 2015, the level of Cantareira decreased from $64 \%$ to $-23 \%$. This great decrease was not a new fact. Already in the period between 2003 and 2004 there was a great decrease of its water level, which reached 4.5\% in January 2004. In 2003 there were already alerts about the incapability of the water system to attend future demands and that supply could only be guaranteed up to 2010 (Folha de São Paulo, October 12, 2003).

The drought is just one among other factors that influenced the ongoing water crisis, and most probably not a central one, as it can be inferred from the information above. The Water Alliance (Aliança pela Água), a group of NGOs and civil society organizations, enumerates other factors, like a water management based on endless resources, the degradation of watersheds and the lack of participation and of transparency by responsible organizations.

A report of the Brazilian National Water Agency-ANA (2013) puts into evidence the problem of disparity between water demand and supply in many Brazilian regions, including the MRSP. If nothing is done, the future scenario will be characterized by an increase of this disparity as a consequence of the Brazilian economic growth. For them it is important to adopt policies to expand water availability as a way to guarantee the attendance of the different demands (p.198). The problem of water availability in MRSP is also described by other studies 
(Porto 2003; Johnsson and Kemper 2005; Rodrigues 2007; FUSP 2009; Ribeiro 2011) and has been in evidence in the literature on water governance in Brazil in the last years.

The current governor ${ }^{2}$ of São Paulo, Geraldo Alckmin, and other representatives have tended to blame the drought as the main cause of the crisis. They ignore the existence of such studies and argue that such a crisis could not have been anticipated (Aith 2015). Julio Cerqueira Cesar, hydraulic engineer, explains that an efficient water system has the capacity to supply water also in periods of drought. He adds that in the last 30 years there was no largescale investment for the amplification of water sources and in the same time the population increased by approximately 10 million in the region (Spresso SP, October 29, 2014).

According to the Brazilian Geographer's Association in Campinas, the water crisis is a political and not a climate issue. What is in crisis is the planned water provision by the state governors. Already ten years ago, when the grant for the State Water and Sanitation Company of São Paulo (Sabesp) ${ }^{3}$ was renewed (2004), it was demanded that they expand the treatment of sewage, reduce dependence on Cantareira and increase the control of water loss in networks. Besides, in 2012 Sabesp alerted their shareholders about the problem, but this information was not transmitted to the population (AGB 2014).

Summing up, there are different views about the origins of the current crisis. The Government of SP tends to point to the drought as the key factor and experts from different fields point to institutional, political, environmental and technical problems in the governance of water.

\section{Conceptual framework, theory and method}

\subsection{Conceptual framework}

The analytical framework used to develop this project is the social-ecological systems (SES) framework (Ostrom 2009, McGinnis and Ostrom 2014). This framework offers a common vocabulary to describe interactions among social and ecological variables in complex socialecological systems. Ecological variables are classified in two categories, Resource Systems (e.g., forests, wildlife, water systems) and Resource Units (e.g., trees and plants, types of wildlife,

\footnotetext{
${ }^{2}$ In 2009, the state government received an alert about the fragility of the Cantareira System. The report on the plan of the High Tietê Basin, the basin in which MRSP is located in, pointed that Cantareira had a great deficit and advised the government to take action to avoid a collapse.

${ }^{3}$ Mixed capital company responsible for providing urban water supply and sewage services in 33 municipalities of MRSP.
} 
amount and flow of water); social variables are classified in Governance Systems (e.g., government and other organizations that manage the resource system, specific rules related to the use of the system, how these rules are made) and Actors (participants of different processes of the SES, like e.g. harvesting, producing, consuming). Interactions among these variables generate Outcomes, which then turn into inputs or set conditions for other Interactions, and so on (see figure 1). Further, these variables are embedded in Social, Economic, and Political Settings and are connected to Related Ecosystems (Nagendra and Ostrom 2014). Within each of these variables categories are second-tier variables.

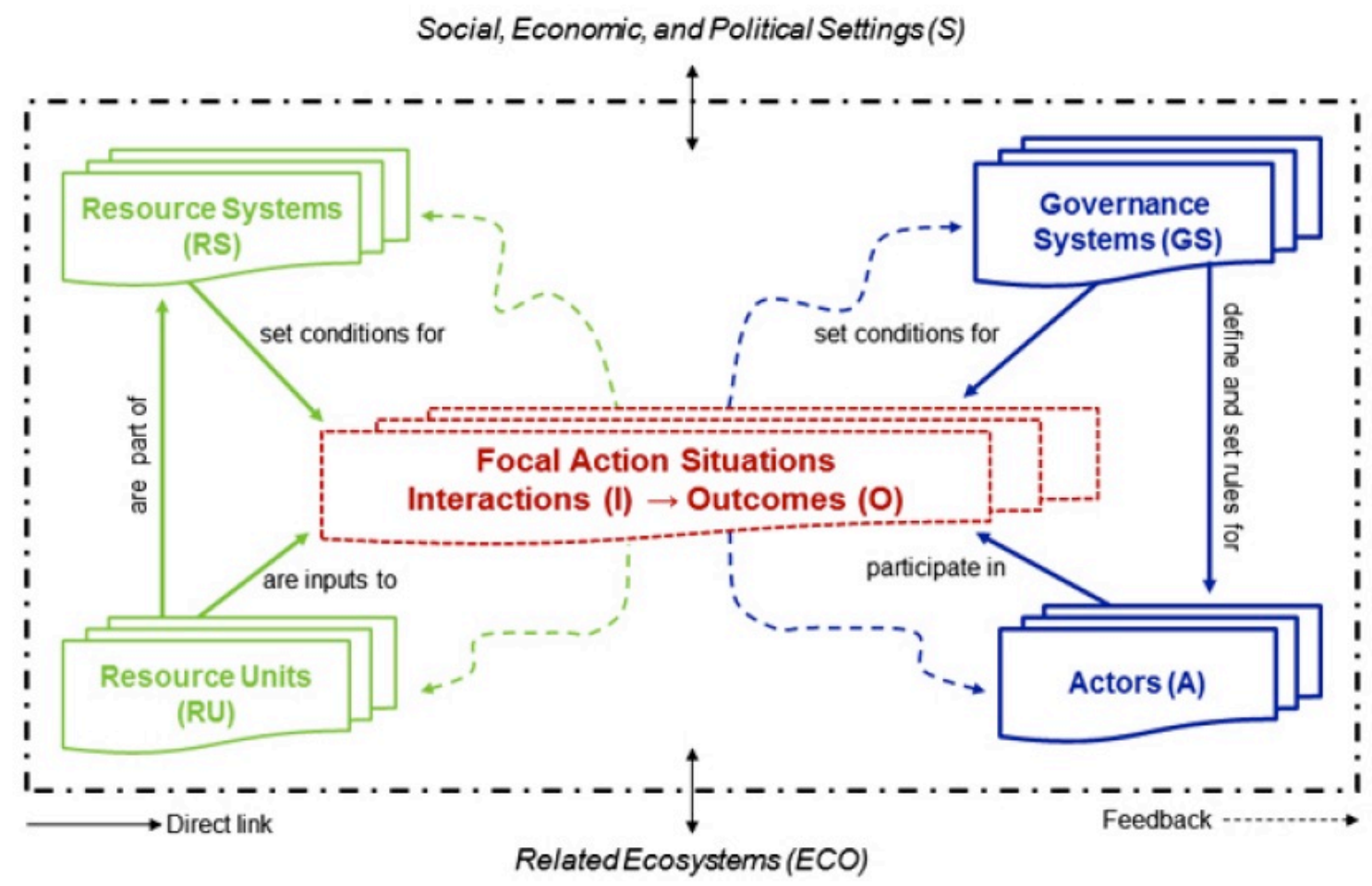

Figure 1. Revised SES Framework with multiple first-tier components

Source: McGinnis and Ostrom 2014.

Depending on the phenomena analyzed, there may be a certain group of variables, which is most helpful in answering a research question. Field studies that apply SES framework (Garrick et al. 2013; Nagendra and Ostrom 2014; Villamayor-Tomas et al. 2016; Murtinho 2016) highlight the importance of identifying the SES variables (see appendix 1), which may be particularly helpful before undertaking the data valuation. This step leads to a focused observation of parameters, which potentially have the strongest explanatory power for a certain question. 


\subsection{Theoretical background}

To be capable to frame the data analysis with adequate variables, a literature review was undertaken to find empirical evidence and theories, which may apply to this case. The theoretical propositions made by Garrick et al. (2013) on the management of hydroclimatic risks in federal rivers is an adequate diagnostic assessment for this study for several reasons. Firstly, both studies focus on regions, which have water scarcity problems and involve a complex institutional network of governance. Secondly, in both the influence of federalism is observed in the development of institutions to access allocation problems. And finally, both are about cases, which concern challenges related to large-scale common-pool resources (CPRs).

The propositions by Garrick et al. are here used to identify an initial set of SES variables, which are potentially explanatory for this case study. These propositions were derived from two bodies of literature: water security/ climate adaptation and institutional fit in large-scale CPR governance. One concerns the first body of literature:

1. Regions with difficult hydrology $y^{4}$ require (comparably) high levels of infrastructure and institutional development to create and share benefits and to achieve tolerable levels of hydroclimatic risks.

And three concern the second body of literature. Out of these three, just two are used here. The proposition that is left aside concerns the interactions between constituent governments of different states, which do not belong to the focus of this work. The two chosen propositions are:

2. Outcomes of water allocation improve with multi-level decision-making venues, monitoring, planning and conflict management to address extended droughts and overallocation.

3. Allocation rules that divide water rights in terms of shares of available supplies share risks better than allocation rules assigning a fixed volume of priority (adapted).

${ }^{4}$ High interannual variability, low mean runoff and high storage (Garrick et al. 2013). 
Each of these propositions is related to a group of second-tier SES variables. The variables on which this study focuses are a mix of those connected to the propositions above and of those which came out during the empirical analysis. These are the rule-making organizations (GS5), the rules-in-use for water governance (GS6), and historic continuity of prior water allocation decisions (GS10). The variable (GS7), about property rights, is not included because it is interpreted as a result of the rules-in-use. GS8 and GS9 are neither suggested as relevant by Garrick et al., nor are they seen as essential for this case study. Concerning the variables GS1 to GS4, they have a more descriptive character of the governance system and are specified in section four. The analyzed interactions include harvesting (I1), information sharing (I2), deliberation processes (I3), conflicts (I4), investment activities (I5) and lobbying activities (I6) that affected the water security in the region and influenced the current crisis (O1).

Concerning the resource system (RS) and resource units $(R U)$, its important particularities are going to be described in the next section, focusing on the second-level attributes (RS3, RS4/8, RS5, RS6, RS7, RU7) connected to the water security proposition. Concerning the actors (A), especially relevant is the variable of importance of resource (dependence) (A8). Additionally, the variables flowing into and out of the focal SES (ECO3), economic development (S1) and demographic trends (S2) were identified as key in understanding water governance in the MRSP.

\subsection{Method}

The study implements an in-depth explanatory case study (Yin 2009) of the current water crisis in the MRSP. Primary evidence was collected from a set of twelve semi-structured interviews with experts, government officials, key operational actors, social and natural scientists, NGO's representatives and politicians in MRSP in March and April 2015. Analysis of newspaper articles, government reports, and scientific publications complemented the interviews. A general interview guideline was used to guide the inquires.

Interviews were conducted in Portuguese, transcribed and analyzed following the principles of Qualitative Content Analysis (Gläser and Laudel 2006), where information is extracted from the sources mentioned above using the Macro collection for qualitative content analysis, and this information is processed separate from its origin. The selected SES variables were used to operate the extraction. Data analysis followed a mixed deductive and inductive procedure similar to the case study of Oberlack et al. (2015). The variables of the SES 
framework structured the coding scheme by interpreting the data as manifestations of the first-tier and relevant second-tier variables.

\section{MRSP as a social-ecological system (SES)}

\subsection{Key aspects of the Resource System and Resource Unit}

The focused sector (RS1) is the water provision in MRSP (see figure 2 for the location of the region). The boundaries (RS2) of the primary resource system of the region are defined by the area of the High Tietê Basin. Of the 39 municipalities that constitute the MRSP, 35 are part of this basin. The size (RS3) of the resource system can be represented by the basin area, which has $5,720 \mathrm{~km}^{2}$ (FUSP 2009). The human constructed facilities (RS4) of the system, also known as gray infrastructure are represented by dams, canals, water transposition networks and wells.

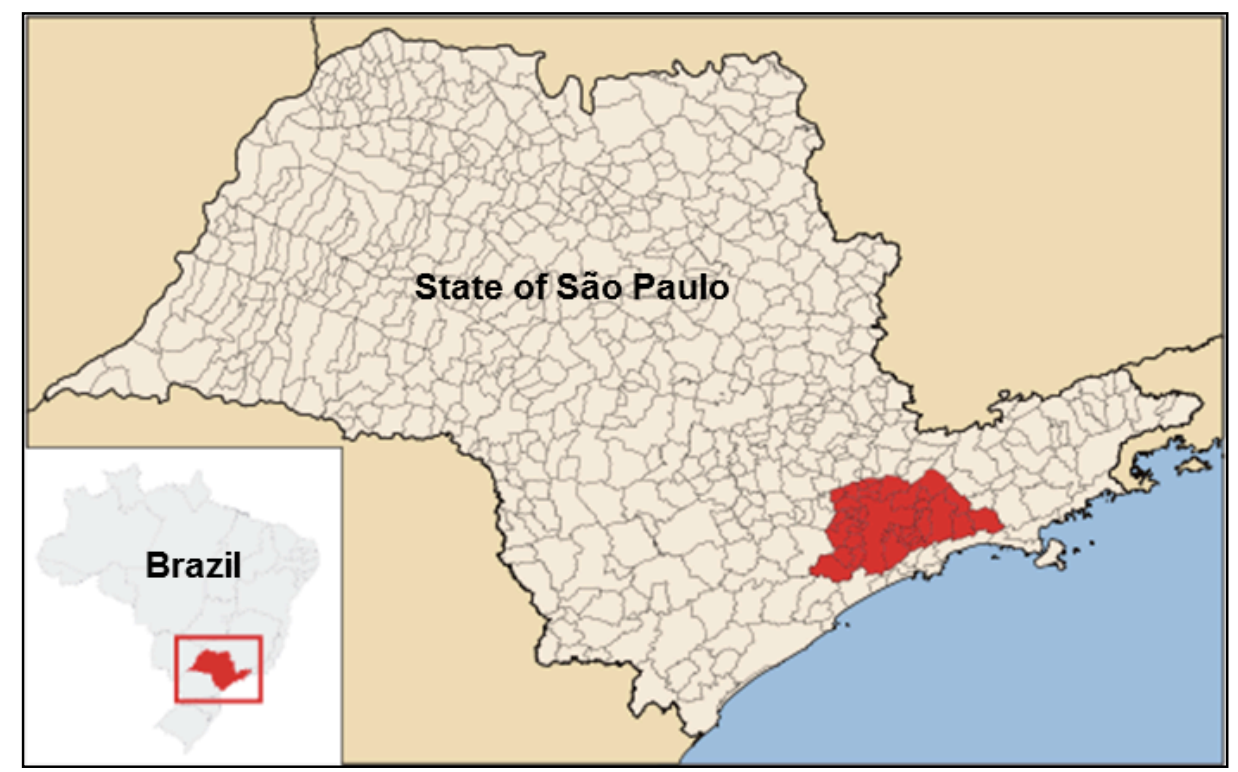

Figure 2: Location of MRSP

Source: Pedro Cardoso de Carvalho e Freitas ${ }^{5}$

5 GFDL (http://www.gnu.org/copyleft/fdl.html), CC-BY-SA-3.0 (http://creativecommons.org/licenses/by-sa/3.0/), via Wikimedia Commons. 
The region (RS9) is surrounded by other water demanders (see appendix 2); east of it there is the Paraiba river tail, which includes the states of Minas Gerais (MG) and Rio de Janeiro (RJ). To the north and south are located the metropolitan regions of Campinas and of Baixada Santista respectively, which have high concentration of population and petrochemical, automobile and textile industries. Therefore, water governance clearly transcends the limits of the MRSP, including other metropolitan regions and other states with which the state of São Paulo (SP) shares water or gets its water from (Ribeiro 2011).

The High Tietê Basin is naturally a region of low water availability due to its location in a riverhead region. The resource system of High Tietê is since the 1970s complemented by the Cantareira system $(E C O 3)^{6}$, which is the transposition of the PCJ (Piracicaba, Capivari e Jundiaí Rivers) Basin. The components in table 1 represent the reservoirs of the Integrated Water Supply System, responsible for water provision in MRSP. Table 2 shows that the total water production in 2009 could be guaranteed just at $80 \%$ of the time, i.e. in $20 \%$ of the months registered in the historical runoffs the amount of water demanded in 2009 could not be produced. Considering this information, the Plan of the High Tietê Basin (FUSP 2009) strongly recommended the expansion of the production units Cantareira, Guarapiranga and Rio Grande to achieve a guarantee of $95 \%$. Based on this fact and on the growing population, the Plan concluded that there was an eminence of collapse of supply (V.2, p.123).

\begin{tabular}{|l|c|c|c|}
\hline \multicolumn{4}{|c|}{ Table 1A: Components of the Resource System of the High Tiete Basin } \\
\hline Component & $\begin{array}{c}\text { Beginning of } \\
\text { use }\end{array}$ & $\begin{array}{c}\text { Distance } \\
(\mathrm{km})\end{array}$ & $\begin{array}{c}\text { Supplied population in 2009 } \\
\text { (millions) }\end{array}$ \\
\hline Alto Cotia & 1914 & 41 & 0.4 \\
\hline Alto Tietê & 1993 & 36 & 3,1 \\
\hline Baixo Cotia & 1960 & 36 & 0.46 \\
\hline Guarapiranga & 1929 & 16 & 3.8 \\
\hline Rio Claro & 1937 & 82 & 1.2 \\
\hline Rio Grande & 1958 & 26 & 1.6 \\
\hline \multicolumn{4}{|c|}{ Table 1B: Flows into focal SES (ECO3). Origin: PCJ Basin } \\
\hline Cantareira & 1973 & 79 & 8.1 \\
\hline
\end{tabular}

\footnotetext{
${ }^{6}$ Also important for neighboring cities of MRSP like Campinas and Piracicaba and to the state of Minas Gerais.
} 


\begin{tabular}{|l|c|c|}
\hline \multicolumn{3}{|c|}{ Table 2: Comparative analysis between production and operational water availability } \\
\hline Component & Production in $2009\left(\mathrm{~m}^{3} / \mathrm{s}\right)$ & Guarantee of the production in 2009 $(\%)$ \\
\hline Alto Cotia & 1 & 100 \\
\hline Alto Tietê & 10 & 100 \\
\hline Baixo Cotia & 0.9 & 98 \\
\hline Cantareira & 33 & 65 \\
\hline Guarapiranga & 14 & 91 \\
\hline Rio Claro & 4 & 100 \\
\hline Rio Grande & 4.8 & 80 \\
\hline Total & 67.7 & 80 \\
\hline
\end{tabular}

Source: FUSP 2009, V.2, p.11.

In what concerns the equilibrium properties (RS6) and system dynamics (RS7), both the supply side and the demand side must be analyzed. Concerning the second one, the Macrometropole Plan ${ }^{7}$ estimated scenarios for water resources demand for public provision, industrial and irrigation uses for the years of 2018, 2025 and 2035 using population projections, further data and assuming that the demand patterns will remain on the same growth path (figure 3) ${ }^{8}$. The difficult hydrology situation in MRSP is related to the conjugation of factors like the high population density of $2,555.27$ habitants $/ \mathrm{km}^{2}(A 1 / S 2)^{9}$, its economic growth perspective (S1), which is translated in increasing water demand in figure 3 and the insufficient production shown in table 2.

\footnotetext{
${ }^{7}$ This plan discusses the relation between urban and economic development in the Macrometropole Paulista (macro region composed by the metropolitan regions of São Paulo, Baixada Santista and Campinas), the limits and possibilities for water offer in the present and future, focusing on the compatibility of water quality and availability with the demand. This plan was written by a consultancy called Coprabe for the State Water Resources Management Agency of São Paulo (DAEE).

${ }^{8}$ Here the groundwater system, which provided around $11 \mathrm{~m}^{3} / \mathrm{s}$ of water in 2009 (FUSP), and the water withdrawal permit given to the Empresa Metropolitana de Águas e Energia S.A. (EMAE), which amounts $27,8 \mathrm{~m}^{3} / \mathrm{s}$ are included, that's why the demand in figure 3 for 2008 is 111 and not something around $67 \mathrm{~m}^{3} / \mathrm{s}$. EMAE uses the water to produce electricity through the Thermoelectric Plant of Piratininga.
}

${ }^{9}$ SEADE 2014.

BRASILIANA- Journal for Brazilian Studies. Vol. 5, n.2 (July, 2017). ISSN 2245-4373.. 


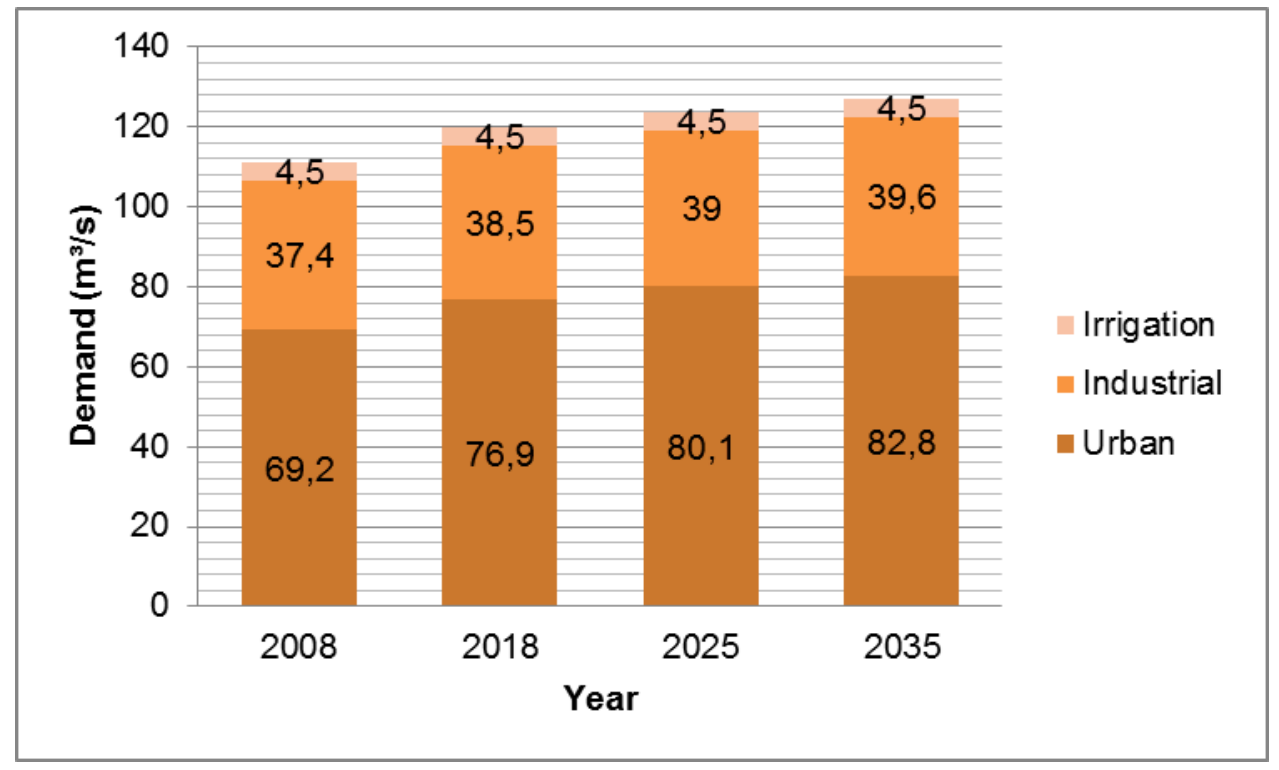

Figure 3: Projection of water demand in the MRSP

Source: Macrometropole Plan, 2013, V.I, p.103

Based on its prospects of demand, the Macrometropole Plan recommends the elaboration of a contingency plan for situations of scarcity and points to the necessity of a new water production component with a large provision capacity. Besides, they recommend water reuse, interference in clouds, payment for environmental services, maintenance of forests in watershed areas and depollution (Macrometropole Plan 2013, V.II, p. 384). Jacobi et al. (2013) argue that combined with complex and irregular urban land uses, the problem of water provision intensifies. "Accelerated rate of urban expansion (S2) into areas of environmental risk and delays in the implementation of adequate infrastructure" (p.13) show that the Brazilian cities are not prepared to face changes. Thus, issues like urban land use and pollution (ECO2) do also play an important role in water security. Most of the rivers and water reservoirs in the metropole have a high level of pollution. The water of one of the biggest dams in the region, the Billings dam, cannot be easily used because of the high costs of cleaning it.

\subsection{Key aspects of the Governance System and Actors}

\subsubsection{Water governance in Brazil (GS6 and GS10)}


The contemporary Brazilian water governance model is a consequence of a process that began between the 1970s and 1980s (Campos and Fracalanza, 2010). Following the Brazilian Constitution of 1988, an important legal milestone was the federal law n 9.433 of 1997, which instituted the National Water Resources Policy (Water Law). The Water Law institutionalized the National Water Resources Management System, constituted of the following governance instruments: water resource plans, bulk water use permits, classification of water bodies, bulk water charging and information systems.

The Water Resources Plan is an instrument to be used in the federal, state and basin levels. Its objectives are inter alia to guide grants, monitoring, charging, information systems; to promote the use, control, protection and recuperation of water resources; to guarantee the equilibrium between water offer and demand and to contribute to the integration between actors (ANA 2013).

One of the innovations of this Management System was the use of economic mechanisms for water management; it introduced the polluter-pays and user-pays principles (Braga et al. 2008). Hence water received a direct economic value in this institutional change. A further innovation was the creation of the basin committees, which are advisory and deliberative bodies, where not just politicians but also water users and civil society representatives have the right to participate. The functions of these committees are inter alia to discuss the plans for their respective basin and the price that will be charged for bulk water use. In what concerns the autonomy to manage water resources, states and the federal government are the responsible actors. But in what concerns the management of water services like waterworks and sanitation, the municipalities are responsible (Braga et al., 2008), which was delegated to Sabesp in the case of the majority of the cities part of MRSP.

To implement this Management System, ANA was created as an organization that has the capacity to act nationally. ANA was established by the law $n^{\circ} 9.984$ in 2000 and has as its function to implement the Water Law and to coordinate water governance, in particular the execution and operationalization of technical and institutional instruments of water management (Braga et al., 2008). ANA is also responsible for regulating the use of federal rivers through bulk water use permits and inspection. ANA has to respect the adoption of basins as management units and acts together with other public and private members of the Management System. 


\subsubsection{Water governance in the state of São Paulo and in MRSP (GS6 and GS10)}

As shown in item 4.1, the region of MRSP coincides with the area of the High Tietê Basin and consequently with the domain area of the Committee of the High Tietê Basin. Nevertheless, as described before, a great amount of the water that supplies the MRSP comes from the Cantareira system, which on the other hand is controlled by the Piracicaba, Capivari and Jundiaí (PCJ) Basin Committee, which unlike the High Tietê is not exclusively a state committee, but a federal committee (located in both São Paulo and Minas Gerais states).

Summarizing, the targeted governance system is constituted by organizations at the High Tietê Basin level, at the state level, at the PCJ basin level and at the national level (GS2). These different levels reveal the complexity of the regime type to be analyzed, which is a federal regime (GS4) and the various types of organizations acting on the water governance that affects about 20 million people (GS3). Based on the information given up to now, the focus of the analysis could be on the rules made by those organizations indicated by the mentioned laws as the highest authorities for water governance in the MRSP, which are at the local (Committee of the High Tietê Basin), state (State Council for Water Resources of São Paulo), regional (Committee of the PCJ Basin) and national levels (National Water Resource Council). Nevertheless, the field research has shown that this approach is too restrictive, because key decisions are not necessarily coming from these committees and councils, but mostly from the SP state government through its water related agencies, which are Sabesp, the Energy, Water Resources and Sanitation Secretariat and the State Water Resources Management Agency of São Paulo (DAEE). Therefore, the analysis was made having an opened approach concerning the observed organizations, allowing for the inclusion of further organizations that were important to answer the research questions.

\section{Results: taking stock and explaining barriers to water security}

This section describes nine barriers to water security that were encountered in the central action situations involving water governance in MRSP. Table 3 provides an overview of these barriers and classifies them according to Ekstrom and Moser's typology (2014, p.167). The text subsequently describes each barrier and explains how they emerged. 
Table 3: Encountered barriers to water security

\section{Barrier}

1. Path dependency

2. Missing contingency plan and rules for droughts

3. Exclusive political system

4. Resistance against water charging

5. Lack of enforcement mechanisms in water plans

6. Sabesp's management model

7. Non-inclusion of water security in the political agenda

8. Metropole model

9. Dialogue between organizations

\section{Type}

politics \& institutional issues

institutional issues

politics

politics

institutional issues

politics \& institutional issues

politics \& expertise

politics

communication

\section{Path dependency}

The conversion of the water governance system in the MRSP to the multi-layered structure designed by the Water Law did not occur. It could be noticed that the rules-in-use are different from those established in the constitutional/collective level of this new model (Constitution of 1988 and Water Law). Concerning the Committee of the High Tietê Basin, according to an informant, its physical proximity to the government of SP hampers its development. The main challenge remains to transform the Committee "from only a social force into an authoritative arena for decision-making" (Johnsson and Kemper 2005, p.41). What prevails then is a water governance structure that is centered in the state government and not distributed in a multilayered structure. Informants speak about "the existence of two structures that do not work harmonically", "the difficulty for the committee to occupy the space for which it was created for", and the "centralization in the state government". Thus, a path dependency on the old state centralized water governance system is identified, which is not necessarily a problem because of centralization itself, but because the state remains under high influence of the same lobby groups as in the past. In a more participatory and representative political system these groups could potentially be put under more pressure and the losses in periods of scarcity might be less unequally distributed.

BRASILIANA- Journal for Brazilian Studies. Vol. 5, n.2 (July, 2017). ISSN 2245-4373.. 
2. Missing contingency plan and rules for droughts

Who has the authority to manage and make decisions in times of crisis? There were no rules to delimit this domain. There are different opinions on which should be the locus for debates and negotiation during crises. Thus, another barrier was the absence of a contingency plan ${ }^{10}$ for a period of scarcity. The Macrometropole Plan discussed this issue and stated that this was one of the items of greatest importance. It also drew attention to the fact that the Basin Plan of High Tietê did not encompass contingency measures for the case of a water provision collapse.

An implication of this problem is that the permission most of the bulk water users have does not consider variations on the allowed amount. In case of a drought, they are fixed. To face a drought period without a rule for this purpose is very complicated; it is much easier to decide on such a rule from an ex-ante perspective. One example is the existence of eight industries in the Cantareira region that have the permit to altogether withdraw $8.4 \mathrm{~m}^{3} / \mathrm{s}$ (Rodrigues and Lobel 2015). The Water Law states that water for human consumption has priority, but it is not clear among other sectors like industry, agriculture, energy, which have the priority under climate extremes. Thus, it is difficult to establish clear reduction targets for these sectors from an ex-post perspective. Furthermore, among Sabesp's clients there are some with special contracts, which guarantee a fixed amount of water provision.

\section{Exclusive political system}

A next barrier is the lack of integration of the community in the water governance system and in the deliberation processes. 6 of 13 interviewees pointed to this fact, some of them expressed that there is a general lack of understanding of what a basin committee is and what its functions are. Few people even know about its existence. Without the participation of the public in the debate governance turns out to be more unequal. There are few organizations of the civil society developing activities to indeed influence decision-making; the majority does not have enough resources to support activism. The lack of participation and of inclusion of many social groups in the political system influences the results of water governance. Those who are politically less organized and less able to put pressure on decision-makers, were the

\footnotetext{
${ }^{10}$ A contingency plan is a normative document that clearly describes risks, actors, responsibilities and actions to be taken in cases of extreme events (Macrometropole Plan 2013, V.I, p. 189).
} 
first to suffer with water provision cuts i.e., people in poorer neighborhoods and homeless people. One of the measures of Sabesp to deal with the low availability of water was to decrease the pressure in the distribution network. One of the consequences of this measure was that people in peripheral regions and in regions with high density of irregular water connections (regions where mostly poor people live) had a higher decrease in water supply ${ }^{11}$. Further, a research undertaken by DATAFOLHA (2014) showed that among the poorest (families with an income up to five times the minimum wage) $41 \%$ had their water supply interrupted for five or more days in the days before the research. Among those families with an income between five and ten times the minimum wage, the rate dropped to $36 \%$. Among those with an income higher than ten times the minimum wage, the rate was even lower, $20 \%{ }^{12}$.

\section{Resistance against water charging}

Bulk water charging is an instrument of water governance that was created by the Water Law. Nevertheless, the creation of this instrument does not mean that its implementation is guaranteed. Different groups were resistant against this water charging and saw it as an additional tax burden. The idea of this pricing is to recognize water as a public good and to indicate its scarcity and to provide a mechanism to allocate a scarce resource. The revenues from this charging are to be used to finance plans, projects, and constructions in the basin where these revenues are levied.

Two sectors were very resistant and organized against this charging, the industrial and agricultural sectors. They have put a lot of pressure on the government and on committees to hinder the implementation of bulk water pricing ${ }^{13}$. These lobbying activities were reported by many of the informants (6), including those which were/are working inside the state. The

\footnotetext{
${ }^{11}$ Information given by one of the interviewees.

${ }^{12}$ Original text in Portuguese: "Entre os mais pobres, com renda familiar mensal de até 5 salários mínimos, $41 \%$ tiveram interrupção do fornecimento de água em casa por cinco dias ou mais durante os últimos dias. Na fatia de renda intermediária, com rende de 5 a 10 salários, o índice cai para $36 \%$, e fica em $20 \%$ entre os mais ricos, com renda familiar superior a 10 mínimos" (DATAFOLHA 2014).

${ }^{13}$ According to Johnsson and Kemper (2005), the "Federation of Irrigators (FAESP) has always demanded that this group be exempt from water charging until rigorous studies prove that they can afford to pay". And "the industrial sector, through its powerful state federation (FIESP), has actively resisted the introduction of any charges for water use"(p.29).
}

3RASILIANA- Journal for Brazilian Studies. Vol. 5, n.2 (July, 2017). ISSN 2245-4373.. 
agricultural sector in the state of SP does not pay for bulk water use in almost all basins of the state. The industrial sector in the region of High Tietê Basin pays a very low price for each $\mathrm{m}^{3}$.

According to Johnsson and Kemper (2005, p.34) this incapacity of the state of SP to implement the bulk water pricing is a sign of failure of the system as a whole. The revenues coming from this charging are one of the financial bases of the committees and agencies activities. When one knows that the budget from committees should come from water bulk charging and this is either not implemented or very low, then it is clear that the committees are not a priority.

\section{Lack of enforcement mechanisms in water plans}

Many interviewees pointed out to the difficulty of putting the basin and state water plans into practice. The Plan of High Tietê already calls attention to the tradition of plans to be just dead letter. Regulations are needed to put new policies into practice, states the plan (p.209). Planning is an important step, but it is not enough. Historically the water plans are not binding. If there are no binding mechanisms, then they are more like a recommendation, because there is nothing that forces them to be incorporated in public and private management. There is no public (federal, state or basin level) instrument that requires actors to incorporate the plan in the management of their activities. The existing plans, says an interviewee, can even have reached a Pareto optimum, a possible negotiated solution. But that is not enough; the next step that should be taken is the design of enforcement mechanisms for these plans. The lack of planning is not a problem, but the execution of these plans, which has the high potential to enhance water security.

\section{Sabesp's management model}

As Sabesp received the renewal of its bulk water use permit for the Cantareira System in 2004 for the following ten years (São Paulo 2004), they agreed to diminish their dependence of this system and to present alternatives to water provision. Sabesp also agreed to make efforts to diminish leaking in networks. The rules to which Sabesp agreed on also established a gradual decrease in water withdrawal in accordance to the level of reservoirs. This meant that deficits during drier periods should be distributed throughout time.

In 2013 Sabesp began the negotiations for the next renewal of this permit (São Paulo 2013). In this document, Sabesp reported the expansion of water production through three 
new projects, which added 5, 0.7 and $4.7 \mathrm{~m}^{3} / \mathrm{s}$ of water. The last one was still not concluded and should cost about 1.6 billion Reais. They reported an investment of about 3.5 billion Reais in a program to reduce leaking and losses and had the target to achieve the level of $19 \%$ of losses by 2020.

Despite these investments, Sabesp was still very dependent on Cantareira's water in 2014 and water losses in networks were still high, about 27\%. In summary, they did not fulfill the obligations they compromised with about ten years ago and nevertheless received in 2014 the prolongation of the permit up to May 2017. Two key questions arise here: why did Sabesp not prioritize these key investments? And: does the Sabesp management model as a private $(49.8 \%)$ and public $(50.2 \%)$ company fit its mission of providing water and sewage services in a sustainable way? The company yielded considerable profits in the past years (see table 4). In the face of the crisis, it was clear what the priorities of the company were. In a period when the effort of employees was most demanded, the company fired at least 560 people until April 2015. $80 \%$ of these worked directly in operations that generate impacts on the population (Valor Econômico, March 16, 2015). According to an informant that worked for the state of SP, operations against leaking were not more widespread because the company had to generate profits. According to this person, Sabesp was neglecting the urgency of the expansion and maintenance of its networks. The lack of the necessary investments to assure water security can be seen as the result of interest conflicts, a political matter (Mercuri 2014). Indeed, the lack of investments on further reuse, maintenance of networks and expansions contributed to the water insecurity. According to a document drafted by different entities that represent actual and previous employees of Sabesp (APU 2015), the company decisions on delay and prioritization of investments are mainly prescriptive (p.6). Yet it is notable to remember that the state of SP receives $50.2 \%$ of the dividends distributed by Sabesp and is not obligated to reinvest this revenue in water services, i.e. this revenue is distributed between different activities of the state. 
Table 4: Sabesp's financial indicators in millions of Reais

\begin{tabular}{|r|r|r|r|}
\hline Year & Profit & Revenue & Investments \\
\hline 2014 & 903,0 & $11.213,2$ & $2.716,0$ \\
\hline 2013 & $1.923,6$ & $11.315,6$ & $2.535,6$ \\
\hline 2012 & $1.911,9$ & $10.737,6$ & $2.440,2$ \\
\hline 2011 & $1.223,4$ & $9.927,4$ & $2.457,3$ \\
\hline 2010 & $1.630,4$ & $9.230,3$ & $1.852,8$ \\
\hline 2009 & $1.373,9$ & $6.730,5$ & $1.960,7$ \\
\hline 2008 & 63,6 & $6.351,6$ & 921,1 \\
\hline 2007 & $1.048,7$ & $5.970,8$ & $2.716,0$ \\
\hline Total: & $10.078,5$ & $71.477,0$ & $17.599,7$ \\
\hline
\end{tabular}

Source of the data: Sabesp

7. Non-inclusion of water security (adaptation) in the political agenda

A further barrier is the non-inclusion of water security and adaptation issues in the political agenda of SP. This issue can hardly be found in the plans of water resources. Other than the São Paulo state, the Ceará state had water management reform on the top of its political agenda and succeeded in implementing water charging already in 1996 (Johnsson and Kemper 2005, p. 43). According to the authors a "strong and determined public sector" was essential to "overcome the skepticism and active opposition of both government agencies and water users" (p.43). According to an informant, it is essential to "mobilize energy and intelligence to get over with business as usual". Besides, when the issue of climate change comes up, some water planners are mostly focused on mitigation issues (diminishing energy consumption, carbon foot print) and not on adaptation ${ }^{14}$.

\footnotetext{
${ }^{14}$ An example for that is the document "Diretrizes para o plano de acao da cidade de São Paulo para mitigação e adaptação às mudanças climáticas" (2009), a plan of the city of São Paulo for mitigation and adaptation measures. In this plan adaptation measures are indirectly mentioned and not really issued.
} 


\section{Metropole model}

One of the difficulties described by the interviewees is the metropole model of São Paulo itself, i.e. the concentration of a huge number of people, activities and services in a specific place. This concentration of demand, which has been barely put into question, poses more challenges concerning the provision of natural resources, including water, to sustain life in this location. Besides, the occupation pattern of the territory that belongs to MRSP has not been ordered and contributed to the devastation of the important green areas in the watersheds. Connected to the occupation pattern of the city is the problem of social inequality and the impossibility of about half of the population in the region to afford a real state with their income. The option for those is informal living, in slums for instance (FUSP 2009, V.I, p.68), many of them in watersheds.

\section{Inadequate dialogue between organizations}

The last barrier is related to the dialogue between organizations. At the state level, there are three main organizations that deal with water-related issues, DAEE, the São Paulo State Environment Agency (CETESB) and Sabesp. To get the coordinators of the three together takes time, says an informant. Besides, there is the difficulty to transform information into a decision-making tool. The articulation between the organizations should improve, to enable the functioning of the integrated system. The Committee and the State Council for Water Resources of São Paulo are the places where this articulation is supposed to take place, but that is not the reality. Johnsson and Kemper (p.15) summarize this problem: "despite having better financial and human resources than other agencies in Brazil, the São Paulo state management agencies were still unable to control, or even to keep up with, the speed and intensity with which water resources in the Alto-Tietê basin were being appropriated and used". This incapacity is also related to the lack of integration between the organizations mentioned above, which work mostly separately and barely articulate decisions.

\section{Discussion}

To warrant reliability to the project, a case-study data base was built. Concerning the internal validity, during the data analysis rival explanations of the research question were addressed and the technique of explanation building was used for the research design. To guarantee

RRASILIANA- Journal for Brazilian Studies. Vol. 5, n.2 (July, 2017). ISSN 2245-4373.. 
construct validity, the data was constituted by various sources, like interviews, water plans, public debates, public committee and council meetings, documentary films, academic journals, newspapers, government and agencies reports. Further, the used sources are related to various organizations and persons, with different political positions and fields of specialization. To discuss the external validity of the results presented in section 5, they will be compared with the propositions presented in the theoretical part of this work. In addition, they will be contrasted with the results of similar case studies.

Concerning the first proposition, it is evident that for the case of MRSP a high level of infrastructure and institutional development are needed for the region to achieve a tolerable level of hydroclimatic risks. The encountered institutional barriers (1, 2, 5 and 6$)$ evidence the fact that the rules and organizations that are part of the water governance system in this region were not sufficiently developed to guarantee water security in a period of enhanced scarcity.

The second proposition calls attention for the importance of multi-level decisionmaking venues, monitoring, planning, and conflict management. Barrier 1 evidences the difficulty to implement such a multi-level decision-making in practice. The lack of enforcement mechanisms in water plans (barrier 5) represents the struggle, which is to implement these plans and to make planning practicable. This struggle was also found in other case studies, like one on water management in Mongolia (Horlemann and Dombrowsky 2012) and another on water governance reforms in South Africa (Herrfahrdt-Pähle 2014). Monitoring is also affected by this barrier, as it is guided by the same water plans. Barrier 6 evidences the problem of deficient monitoring concerning the accomplishment of Sabesp with the rules for bulk water use they agreed with ten years ago. Conflict management to address extended droughts and overallocation was also not well developed in MRSP, what is put into evidence by barriers 2 and 6 .

Barrier 2 is also connected to the third proposition, which calls for the importance to have water rights in terms of shares of available supplies rather than as a fixed volume of priority. The lack of proportionality in the bulk water use permits is indeed a problem. Further, the existence of ex-ante proportional rules could have helped in the more efficient management of water allocation. An example of a successful case in this sense is the drought governance in Catalonia between 2007 and 2008, for which priorities of water use in accordance to water levels of reservoirs were assigned by the Decree 84/2007 from the 
Regional Government of Catalonia ${ }^{15}$. The water management in accordance to demand side measures guaranteed that in spite of the drought, households had a guaranteed level of water available for basic needs.

Above, the barriers connected to institutional issues were compared to the propositions made by Garrick et al. The encountered barriers are nevertheless not restricted to this barrier type; five of them have a political character, i.e. they concern issues like lack of political will, political agendas, unwillingness to share resources and political positioning (e.g., Ekstrom and Moser 2012, p.168). The aforementioned propositions are valuable for the explanation of the barriers to water security in this case study but they are not sufficient. The barriers related to politics are just partially related to these propositions. There is evidence from this research that other factors are also important for the robustness of a SES facing hydroclimatic struggles like droughts. Power relations also play a key role. The government makes decisions under considerable pressure of specific interest groups (barrier 4). The political system remains exclusive due to the path dependency of old power structures (barrier 1) and this also affects the broader governance system, which tends to favor specific groups in the allocation of financial and natural resources. Besides, the last governments in the region did not challenge the metropole model (barrier 8), i.e. the land occupation paradigm that remains. The concentration of capital and production triggers huge demand for water in the region. However, there was hardly any government that deeply rethought São Paulo's growth and water demand in the last decades.

Further, there is a considerable gap in the structures of water governance in what concerns democratic participation (barrier 3). According to Engle and Lemos (2010), "in theory, more flexible, democratic, and participatory designs are hypothesized to increase adaptive capacity" (p.6). They remember that there are few examples that confirm this hypothesis. Concerning this case study, the lack of participation was not necessarily identified as a key barrier to water security, but the misrepresentation of the interests of the population in having a secure water provision and the risky behavior of water managers (Sabesp and government). The current president of Sabesp, Jerson Kelman, argues that if water withdrawal would have been proportional to water inflow in the system since 2012, when water levels began to drop, the level of the system would have decreased much less than it did (Leite 2015).

15 "The Catalan Decree established four different drought scenarios according to the reservoir levels: pre-alert, exceptional level 1, exceptional level 2 and emergency" (Martin-Ortega and Markandya 2009, p.7).

RRASILIANA- Journal for Brazilian Studies. Vol. 5, n.2 (July, 2017). ISSN 2245-4373.. 
The other two types of encountered barriers, expertise (barrier 7) and communication (barrier 9) are also evident in other contexts, like e.g. the San Francisco Bay, where Ekstrom and Moser (2012) also encountered lack of communication and of expertise among key decision-makers. The absence of such barriers would not nevertheless be sufficient to guarantee water security. As highlighted by Villamayor-Tomas et al. (2014), communication is identified rather as a prerequisite for cooperation. The same applies for expertise, since the knowledge about climate change and adaptation does not necessarily imply that a decisionmaker will prioritize this issue in the political agenda, which is why barrier 7 is also classified in the politics type.

\section{Conclusion}

The described barriers indicate that political struggles have a big influence on the allocation of water resources and on investments in infrastructure related to the distribution of water. Water insecurity is a complex outcome and was here described as the result of different interactions at various governance levels.

Concerning the central research question, it can be asserted that the reason for the low resilience of MRSP to droughts is highly related to institutional and political factors. More specifically, it is related to factors like the predominance of the representation of certain groups in the state of São Paulo and to the absence of ex-ante institutional tools to share hydroclimatic risks. It could be observed that the lack of specific governance mechanisms and the political power concentration, which characterize the actual governance system, are central in the explanation of the water crisis. This crisis is the symptom of a bigger problem, which is the inability of the existent governance structure to successfully manage and share risks in the field of water provision. The risk that the de facto water managers (Sabesp and SP) took is not tolerable, as they put into risk the quality of water provided for human consumption and the availability of this water.

The study reveals that the politicization of water issues is a major barrier to adaptation. In densely populated and highly economically concentrated areas like MRSP, the challenges to cope with climatic variations are enhanced. Comparative studies on water governance between MRSP and similar metropolitan areas have the potential to complement the insights of this research and to offer an interesting discussion of the here presented findings. 


\section{References}

ANA. 2013. Conjuntura dos recursos hídricos no Brasil. Agência Nacional das Águas (Brasil).

Biesbroek, G. R., J. E. M. Lostermann, C. J. A. M. Termeer, and P. Kabat .2013. On the nature of barriers to climate change adaptation. Regional Environmental Change 13(5):1119-1129. doi: 10.1007/s10113-013-0421-y

Braga, B., R. Flecha, D. S. Pena and J. Kelman. 2008. Pacto federativo e gestão de águas. Estudos Avançados 22(63):17-42. DOI: 10.1590/S0103-40142008000200003

Brasil. 1997. Lei no 9.433, de 8 de janeiro de 1997. Da Política Nacional de Recursos Hídricos. Available at: http://www.planalto.gov.br/ccivil_03/LEIS/L9433.htm (Accessed October 28, 2016).

. 2000. Lei no 9.984, de 17 de julho de 2000. Dispõe sobre a criação da Agência Nacional de Águas - ANA. Available at:

http://www.planalto.gov.br/ccivil_03/LEIS/L9984.htm (Accessed October 28, 2016).

Campos, V. N. O. and A. P. Fracalanza .2010. Governança das águas no Brasil: conflitos pela apropriação da água e a busca da integração como consenso. Ambiente $\mathcal{E}$ Sociedade Campinas 13 (2):365-382. doi: 10.1590/S1414-753X2010000200010

DATAFOLHA Instituto de Pesquisas. 2014. Termômetro Paulistano. Crise da água em São Paulo. Available at: http:// datafolha.folha.uol.com.br/opiniaopublica/2014/10/1535230-para-75falta-de-agua-emsp-poderia-ter-sido-evitada-por-governo.shtml (Accessed June 14, 2017).

Eisenack, K. and R. Stecker. 2012. A Framework for Analysing Climate Change Adaptations as Actions. Mitigation and Adaptation Strategies for Global Change 17(3):243-260. doi: 10.1007/s11027011-9323-9

Eisenack, K., S. Moser, E. Hoffmann, R. Klein, C. Oberlack, A. Pechan, M. Rotter, and C. Termeer. 2014. Explaining and overcoming barriers to climate change adaptation. Nature Climate Change 4:867-872. doi:10.1038/nclimate2350

Ekstrom, J. A. and S. C. Moser. 2012. Identifying and overcoming barriers in urban adaptation efforts to climate change: case study findings from the San Francisco Bay Area, California, USA. Urban Climate 9 (September): 54-74. doi: http://dx.doi.org/10.1016/j.uclim.2014.06.002.

RRASILIANA- Journal for Brazilian Studies. Vol. 5, n.2 (July, 2017). ISSN 2245-4373.. 
Engle, N.L. and M.C. Lemos. 2010. Unpacking governance: Building adaptive capacity to climate change of river basins in Brazil. Global Environmental Change 20:4-13. doi: http://dx.doi.org/10.1016/j.gloenvcha.2009.07.001

FUSP. 2009. Plano da Bacia Hidrográfica do Alto Tietê. Relatório Final. Volume 1 e 2. Fundação de Apoio à Universidade de São Paulo (FUSP).

Garrick, D., L. De Stefano L, F. Fung, J. Pittock, E. Schlager, M. New, and D. Connell. 2013. Managing hydroclimatic risks in federal rivers: a diagnostic assessment. Philosophical Transactions of the Royal Society A371: 20120415. doi: 10.1098/rsta.2012.0415

Gläser, J. and G. Laudel. 2006. Experteninterviews und qualitative Inhaltsanalyse [Expert Interviews and Qualitative Content Analysis]. Wiesbaden, Germany: Verlag für Sozialwissenschaften.

Grey, D., C.W. Sadoff. 2007. Sink or Swim? Water security for growth and development. Water Policy 9:545-571. doi: 10.2166/wp.2007.021

Grey, D., D. Garrick, D.Blackmore , J. Kelman, M. Muller, and C. Sadoff .2013. Water security in one blue planet: twenty-first century policy challenges for science. Philosophical Transactions of the Royal Society, A371: 20120406. doi: 10.1098/rsta.2012.0406

Herrfahrdt-Pähle, E. 2014. Applying the concept of fit to water governance reforms in South Africa. Ecology and Society 19(1):25. doi: http://dx.doi.org/10.5751/ES-05964-190125

Horlemann, L. and I. Dombrowsky. 2015. Institutionalising IWRM in developing and transition countries: the case of Mongolia. Environmental Earth Sciences 65:1547. doi:10.1007/s12665-011-1213-7

Jacobi, P. R., M. G. A. da Paz , R. D. Leão, and L. M.B. Estancione. 2013. Water governance and natural disasters in the Metropolitan Region of São Paulo, Brazil. International Journal of Urban Sustainable Development 5(1):77-88. doi: http://dx.doi.org/10.1080/19463138.2013.782705

Johnsson, R. M. F. and K. E. Kemper. 2005. Institutional and Policy Analysis of River Basin Management. The Alto-Tietê River Basin, São Paulo, Brazil. World Bank Policy Research Working Paper 3650, June 2005. doi: http://dx.doi.org/10.1596/1813-9450-3650

Klein, R. J. T. and S. Juhola. 2014. A framework for Nordic actor-centered adaptation research. Environmental Science \& Policy 40:101-115. doi: 
http://dx.doi.org/10.1016/j.envsci.2014.01.011

Lehmann, P., M. Brenck, O. Gebhardt, S. Schaller, and E. Süßbauer. 2013. Barriers and opportunities for urban adaptation planning: analytical framework and evidence from cities in Latin America and Germany. Mitigation and Adaptation Strategies for Global Change 20:75-97. doi: 10.1007/s11027-013-9480-0

Macrometropole Plan. 2013. Copabre. Plano Diretor de Aproveitamento de Recursos Hídricos para a Macrometrópole Paulista, no Estado de São Paulo. Relatório Final. Volumes I e II.

Martin-Ortega, J. and A. Markandya. 2009. The costs of drought: the exceptional 2007-2008 case of Barcelona. BC3 Working Paper Series 2009-09. Basque Centre for Climate Change (BC3). Bilbao, Spain.

McGinnis, M. D. and E. Ostrom. 2014.Social-ecological system framework: initial changes and continuing challenges. Ecology and Society 19(2): 30. doi: http://dx.doi.org/10.5751/ES-06387190230

Murtinho, F. 2016. What facilitates adaptation? An analysis of community-based adaptation to environmental change in the Andes. International Journal of the Commons 10(1):119-141. doi: http://doi.org/10.18352/ijc.585

Nagendra, H. and E. Ostrom. 2014.Applying the social-ecological system framework to the diagnosis of urban lake commons in Bangalore, India. Ecology and Society 19(2):67. doi: http://dx.doi.org/10.5751/ES-06582-190267

Oberlack, C. 2014. Institutional Diagnostics of Climate Adaptation. Constitutional Economics Network Working Paper Series. ISSN No. 2193-7214. CEN Paper nº1-2014.

. 2016. Diagnosing institutional barriers and opportunities for adaptation to climate change. Mitigation and Adaptation Strategies for Global Change 22(5):805-838. Springer. doi: http://dx.doi.org/10.1007/s11027-015-9699-z

Oberlack, C., P. L. Walter, J. Schmerbeck, and B.K. Tiwari. 2015. Institutions for Sustainable Governance of Forests: Equity, Robustness and Cross-level Interactions in Mawlyngbna, Meghalaya, India. International Journal of the Commons 9(2):670-697. doi: http://doi.org/10.18352/ijc.538

RRASILIANA- Journal for Brazilian Studies. Vol. 5, n.2 (July, 2017). ISSN 2245-4373.. 
Ostrom, E. 2005. Understanding institutional diversity. Princeton, NY, USA: Princeton University Press.

. 2009. A General Framework for Analyzing Sustainability of Social-Ecological Systems. Science 325:419-422. doi: 10.1126/science.1172133

Porto, M. 2003. Recursos Hídricos e Saneamento na Região Metropolitana de São Paulo: Um desafio do tamanho da cidade. Agua Brasil series ; no. 3. Brazil Water Resources. Washington DC : World Bank Group.

Ribeiro, W.C. 2011. Oferta e estresse hídrico na região Metropolitana de São Paulo. Estudos Avançados 25 (71):119-133. doi: http://dx.doi.org/10.1590/S0103-40142011000100009

Rodrigues, F.A. 2007. (In)eficácia do modelo brasileiro de gestão de recursos hídricos: a experiência da RMSP. Instituto de Geociências, pós-graduação Geociências. Campinas, São Paulo, Brazil, 369.

São Paulo. 2004. Secretaria de Estado de Energia, Recursos Hídricos e Saneamento. Departamento de Águas e Energia Elétrica (DAEE). Portaria DAEE no. . 1213, de 06 de Agosto de 2004. Outorgada à Companhia de Saneamento Básico do estado de São Paulo - SABESP.

. 2013. Secretaria de Estado de Energia, Recursos Hídricos e Saneamento. Departamento de Águas e Energia Elétrica (DAEE). Renovação da Outorga do Sistema Cantareira 2014. Oficio DAEE/SUP/0965/2013, de 24.07.2013.

Villamayor-Tomas, S., F. D. Fleischman, I. P. Ibarra, A. Thiel and F. van Laerhoven. 2014. From Sandoz to Salmon: Conceptualizing resource and institutional dynamics in the Rhine watershed through the SES framework. International Journal of the Commons 8(2):361-395. doi: http://doi.org/10.18352/ijc.411

Villamayor-Tomas, S., M. Avagyan, M. Firlus, G. Helbing, and M. Kabakova. 2016. Hydropower vs. fisheries conservation: a test of institutional design principles for commonpool resource management in the lower Mekong basin social-ecological system. Ecology and Society 21(1):3.

doi: http://dx.doi.org/10.5751/ES-08105-210103

Wang, X., Z. Jian-yun, S. Shahid, X. Xing-hui, H. Rui-min, and S. Man-ting. 2014. Catastrophe theory to assess water security and adaptation strategy in the context of environmental change. Mitigation Adaptation Strategy Global Change 19:463-477.doi:10.1007/s11027-012-9443-x 
Yin, R. K. 2009. Case Study Research. Design and Methods. Thousand Oaks, California, USA: Sage Publications. $3^{\text {rd }}$ edition.

\section{Internet sources:}

AGB -Associação dos Geógrafos Brasileiros-Campinas. "Crise hídrica, uma crise política", last modified October 23, 2014, accessed October 25, 2016, http://agbcampinas.com.br/site/2014/crise-hidrica-crise-politica.

Aith, M. “O apagão de fatos”, Folha de São Paulo, January 01, 2015, http://app.folha.uol.com.br/\#noticia/514528.

Folha de São Paulo . "SP só atende demanda de água até 2010", Folha de São Paulo, October 12, 2003, http://www1.folha.uol.com.br/folha/ciencia/ult306u10308.shtml.

Folha de São Paulo ."Corte no abastecimento de água atinge 60\% dos paulistanos, diz Datafolha." October 20, 2014, http://www1.folha.uol.com.br/cotidiano/2014/10/1535091-corteno-abastecimento-de-agua-atinge-60-dos-paulistanos-diz-datafolha.shtml.

Leite, F. "Sabesp poderia ter evitado uso do volume morto do Cantareira", O Estado de S. Paulo, May 07, 2015, http://sao-paulo.estadao.com.br/noticias/geral,sabesp-poderia-terevitado-uso-do-volume-morto-do-cantareira,1682611.

Mercuri, C. "O colapso da água em São Paulo", Revista Forum, May 16, 2014, http://www.revistaforum.com.br/digital/147/o-colapso-da-agua-em-sao-paulo/.

Rodrigues, A. and F. Lobel.“Oito indústrias de SP têm o dobro da água de toda a cidade de Campinas", May 05, 2015, http://www1.folha.uol.com.br/cotidiano/.

Spresso SP. "SP: por trás da falta d'água, privatização e ganância",October 29, 2014, http://spressosp.com.br/2014/10/29/sp-por-tras-da-falta-dagua-privatizacao-e-ganancia/.

Valor Econômico. "Funcionários da Sabesp aceitam suspender greve até dia 23", March 16, 2015, http://www.valor.com.br/empresas/3956710/funcionarios-da-sabesp-aceitam-suspendergreve-ate-dia-23. 
APU-Associação dos Profissionais Universitários da Sabesp et al. “Proposta para a nova gestão da Sabesp", January, 2015, accessed October 28, 2016, http://www.apu.com.br/assets/imagens/publicacoes/publicacoes_20150126094815.pdf.

Sabesp. "Indicadores Financeiros", accessed October 28, 2016, http://www.sabesp.com.br/CalandraWeb/CalandraRedirect/?temp=4\&proj=investidoresnovo\& $\mathrm{pub}=\mathrm{T} \& \mathrm{db}=\&$ docid $=842251991 \mathrm{~A} 09555 \mathrm{~B} 832570 \mathrm{DF} 006605 \mathrm{BA} \&$ docidPai $=$ AB82F8DBCD12AE488 325768C0052105E\&pai=filho6\&filho=neto-1.

Sabesp. "Situação dos Mananciais", accessed October 26, 2016, http://www2.sabesp.com.br/mananciais.

Atlas ANA . 2010. "Região Metropolitana de São Paulo", accessed October 26, 2016, http://atlas.ana.gov.br/Atlas/. 


\section{Appendix 1}

Table A1.1. Coding scheme: second-tier variables of the SES framework (adapted from McGinnis and Ostrom 2014)

\section{Social, economic, and political settings (S)}

S1 Economic development, S2 Demographic trends, S3 Political Stability, S4 Other governance systems, S5 Markets, S6 Media organisations, S7 Technology

\section{Resource Systems (RS)}

RS1 Sector

RS2 Clarity of system boundaries

RS3 Size of resource system

RS4 Human-constructed facilities

RS5 Productivity of system

RS6 Equilibrium properties

RS7 Predictability of system dynamics

RS8 Storage capacities

RS9 Location

\section{Governance Systems (GS)}

GS1* Policy area

GS2* Geographic scale of governance system

GS3* Population

GS4* Regime type

GS5* Rule-making organizations

Public sector organization

Private sector organizations (for-profit)

Nongovernmental, non-profit organizations

Community-based organization

Hybrid organizations

GS6* Rules-in-use

Operational-choice rules

Collective-choice rules

Constitutional-choice rules

GS7* Property-rights systems

GS8* Repertoire of norms and strategies

GS9* Network structure

GS10* Historical continuity 


\section{Resource Units (RU)}

RU1 Resource unit mobility

RU2 Growth or replacement rate

RU3 Interaction among resource units

RU4 Economic value

RU5 Number of units

RU6 Distinctive characteristics

RU7 Spatial and temporal distribution

\section{Actors (A)}

A1 Number of relevant actors

A2 Socioeconomic attributes

A3 History or past experiences

A4 Location

A5 Leadership/entrepreneurship

A6 Norms (trust-reciprocity)/ social capital

A7 Knowledge of SES/mental models

A8 Importance of resource (dependence)

A9 Technology available

\section{Action Situations: Interactions (I) $\rightarrow$ Outcomes (O}

Interactions (I) (Activities and Processes)

I1.1 Harvesting

I1.2 Information sharing

I1.3 Deliberation

processes

I1.4 Conflicts

I1.5 Investment activities

I1.6 Lobbying activities

I1.7 Self-organising

activities

I1.8 Networking

activities

I1.9 Monitoring activities

I1.10 Evaluative activities

\section{Outcomes (O)}

O1 Social outcomes

O2 Ecological outcomes

\section{Related Ecosystems (ECO)}

ECO1 Climate patterns, ECO2 Pollution patterns, ECO3 Flows into and out of focal SES 


\section{Appendix 2}

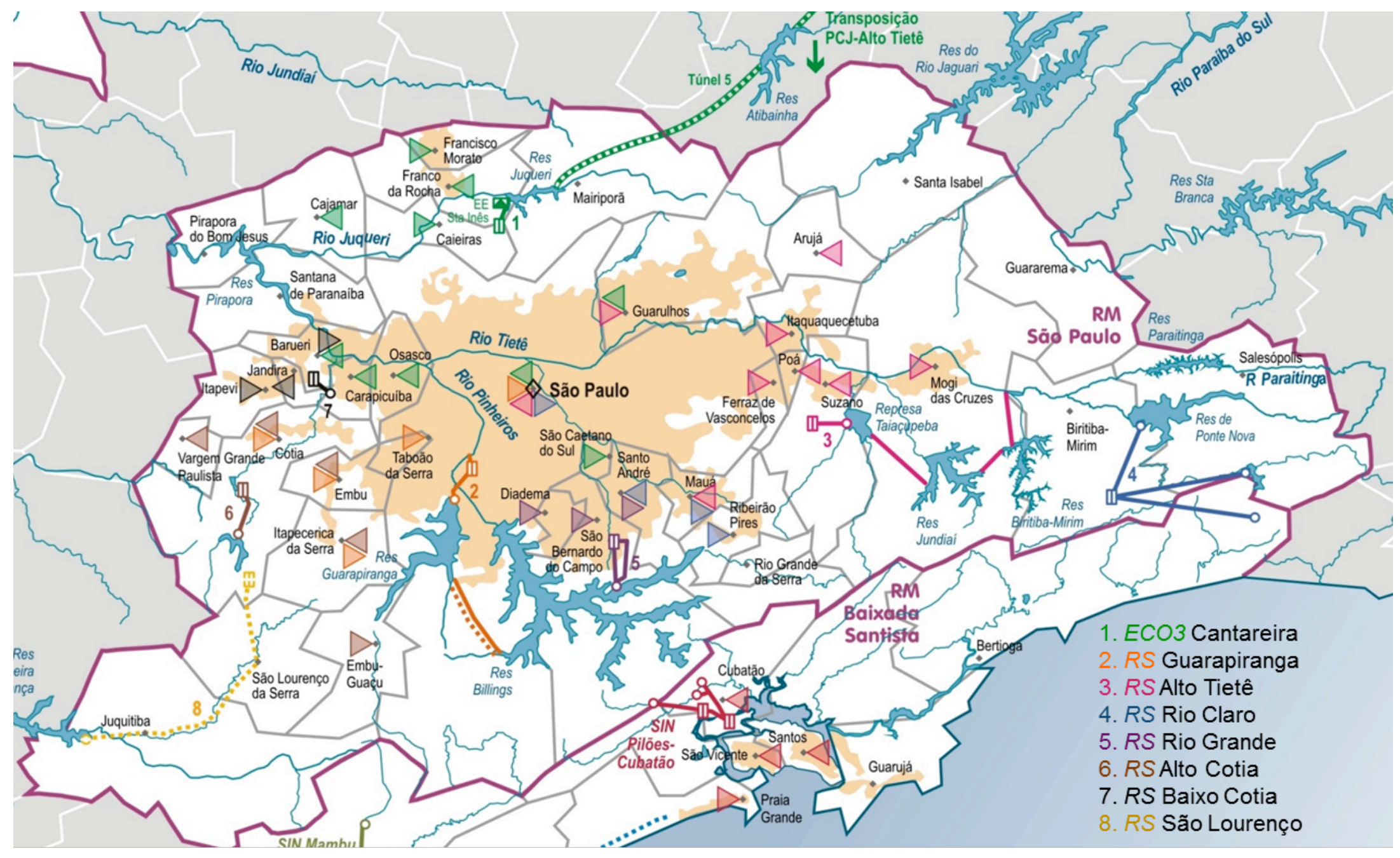

Figure A2.1. MRSP and its neighborhoods Source: Atlas ANA 2010 